\title{
Intellectual Capital and Firm Performance of Listed Firms In Nigeria: Moderating Role of Corporate Governance
}

\author{
Adesanmi Timothy Adegbayibi \\ Department of Accounting, Faculty of Social and Management Sciences, \\ Adekunle Ajasin University, Akungba Akoko, Ondo State, Nigeria \\ Email: adesanmi.adegbayibi@aaua.edu.ng
}

\begin{abstract}
The low performance of Nigerian firms despite investment in intellectual capital is a major concern. While studies have shown that corporate governance practices strengthens the subsisting relationship between investment in intellectual capital and performance in the developed economies, this moderating effect in Nigeria is yet to be adequately explored as research focus is limited to possible effects of intellectual capital and performance. It is against this background, this study investigated the moderating role of corporate governance on the relationship between intellectual capital and performance of listed non-financial companies in Nigeria. The study adopted ex-post facto research design, and data were drawn from the audited annual reports of fifty (50) listed non-financial firms for a period of 2007 to 2017. Multiple regression techniques were employed to test the relationship among the variables. The results of the study revealed that both intellectual capital and corporate governance drive financial performance as the relationship is found significant in all components. The study concluded that corporate governance moderated the effect of investment in intellectual capital on financial performance. The study recommends that Board of directors should adopt measurable corporate governance mechanism which strengthens and helps in investment strategy that increases and improves performance. Also, there is need to entrench corporate governance as a control strategy and impetus towards attaining organization's goals.
\end{abstract}

Keywords: Corporate Governance; Firms’ Performance Intellectual Capital; Non-financial Firm

\section{Introduction}

The changeover to digital economy has brought home the idea of adding intellectual capital (IC) to the measurement of organizational performance (Marr, Schiuma \& Neely, 2004). For any organisation to optimally utilise its human resources, emphasis must be given to the workability of IC in the organisation as a critical factor for a competitive edge and its contribution to the organisational result. IC gained impetus because of groundbreaking study of Pulic (1998) measuring the nexus of IC and performance of companies.

The recent trends in the world as it relates to the development of the knowledge-based economy, as well as economic events (such as economic crisis, constant innovation and so on) is a pointer to the need for investment in IC and such investment in Nigeria and international community have made competition intense among both local and multinational business corporations. The Nigeria Petroleum Development Company (NPDC), Exxon Mobil, Access Bank Plc., Unilever Plc, Chevron Plc., are the leading firms. For instance, over $\$ 40$ million was invested in 2008 in the training of Unilever Plc's employees. Exxon's main business unit spent \$117 million in workforce preparation in 2014 to retain its strategic edge in the industry (ExxonMobil Corporate Citizenship Report, 2014).

The global economic recession has a ripple effect on the performance of Nigerian firms despite investment in IC. This has become a major concern for investors, stakeholders, accounting professionals. In spite of the essentiality of IC, extant literature shows that the results from empirical research remained contradictory and inconsistent. For example, studies such as Chen, Cheng \& Hwang (2005); Clarke, Tan, Plowman \& Hancock, (2007); Clarke, Seng \& Whiting, (2011); Alipour (2012) report that IC significantly affects firm efficiency whereas Chan, (2009); Firer \& Williams, (2003), Onyekwelu, Okoh \& Iyidiobi, 2017 among others do not at all report any significant relationship.

Extant literature has proved that investing in human capital is not a guarantee of high performance except corporate governance mechanism is put in place to 
ensure efficient and effective management of organization's resources (Obigbemi, et al, 2016; Irawanto, Gondomono, \& Hussein, 2017). Board of directors must double up in his oversight function to ensure effective decision making and management of economic resources which is key and crucial to the attainment of organizational goal. It is clear in the literature the significant role that can be played by corporate governance in driving economic value and enhancing performance of economic units (Irawanto, et al, 2017; Aslam, et al, 2018; Aftab, Khurshid, \& Yousaf, 2019).

Today, the relationship between investment decisions, either physical or IC, and performance is seen to be strengthened with the presence of corporate governance (Aslam el al., 2018; Aftab el al., 2019). The adoption of measurable corporate governance mechanism helps in investment strategy that increases and improves performance. There is ongoing campaign for the need to entrench corporate governance as a control strategy and impetus towards attaining organization's goals. Studies have confirmed a structural shift in corporate governance and high level of compliance among firms in Nigeria (Akinkoye \& Olasanmi, 2014; Gyamerah, \& Agyei, 2016; Araniyar \& Chizea, 2017; Aiwanehi, et al, 2018).

Studies have also shown a common ground between financial performance and the corporate governance, while in Africa most especially in Nigeria there are few empirical evidences on corporate governance activities. In addition, some prior studies would either investigate the role or consequence of IC on financial performance (Kurfi, Udin, \& Bahamman, 2017; Onyekwelu, Okoh, \& Iyidiobi, 2017; Nassar, 2018) whilst some looked at the influence of corporate governance activities on corporate performance (Basyith, 2016; Olayiwola, 2018; Adesanmi, et al, 2018; İlhan, 2019). Meanwhile, this study combined IC with corporate governance as a moderating variable either influencing financial performance positively or negatively relating it to non-financial companies in Nigeria.

Adegbite (2012) made available certain evidence to back-up the view that a nation's peculiar institutional arrangements influence its principal model and style of corporate governance regulations. Hence, scarcity of empirical corporate governance studies in Africa as a whole and Nigeria in particular is a major concerned. There seems to be very few studies in Nigeria on the moderating role of corporate governance on the link between IC and financial performance. Some other studies conducted in Nigeria only examined the impact of individual corporate governance variable on performances (e.g. Adetunji \& Olawoye, 2009; Adegbite, 2012; Akinkoye \& Olasanmi, 2014). The clashing evidences may partially be described by the fact that previous studies suffered from procedural problems, less unrepresentative size sample, and untenable choices for the proxy of company's performance and inapt time frames.

Most studies (Anuonye, 2015; Onyekwelu et. al., 2017; Nwaiwu \& Nwaekpe, 2018) looked at the influence of IC on firms' performance neglecting the corporate governance variables such as board characteristics and the ownership structure despite its moderating roles as enacted by the code of corporate governance. This study introduces a moderating variable of corporate governance mechanisms such as audit committee size, board size, proportion of attendance in meeting and proportion of independent directors in audit and risk committee which has not been tested before in a Nigerian context in relation to IC and financial performances. The interplay or the interaction among the concerned variables particularly the moderating role played by corporate governance is yet to be adequately examined, hence the need for this study.

\section{Literature Review}

\section{Intellectual Capital}

Intellectual capital (IC) is the knowledge-based assets which the organization focuses on to increase its efficiency of the financial performance. It is further categorized into human, structural and customer capital. Human capital is the mixture of innate legacy, education, experience and attitude about life and business, structural capital in the form of managerial procedures is the serious connection which allow IC to be dignified 
organization level while customer or relational capital is the combination of assets used by business in relating with its past, present and potential customers, with its network of suppliers or research and development partners, in addition to the perceptions and views that they hold about the company (Brannstrom \& Giuliani, 2009).

In simple term, IC refers to knowledge, intellectual property and experience available in a firm that can be put to use in order to create wealth and add value. It was described as a collective knowledge of the individuals in an organization or society (Payam \& Mohammad, 2013). According to Chizari et al (2016), IC are the innate attributes usually acquired by a firm which drives it on the wheel of value creation, value addition, and organization financial performance. Also, Nasar (2018) posit that IC is highly important for value creation in this century economies and organizations. This is because present economies are driven by knowledge-based and highly depending on knowledge assets rather than physical assets to increase its competitive advantages.

This explains the reason why several organizations keep enhancing their employee skills through training, research, and development; investing greatly in customer relations and most of all information technology systems. In researches, three factors combined together are referred to as IC namely; the human capital of a company which comprises of all its human resources the expertise, experience, skills and abilities to perform jobs and tasks. Another component of IC is the structural capital which consists of the organizational resources like systems, procedures and culture of how work is organized and done. The last aspect is the relational capital which comprises the links built for external business relations with customers, suppliers, investors, and communities.

\section{Corporate Governance}

According to OECD (2004), it is the relationship that exists between the owners, management and other relevant stakeholders of a firm, which influences the formation of its objectives and how performance is measured. Bezawada (2020) defined corporate governance as the organizational structure that seeks to enhance the achievement of corporate objectives. Corporate governance depicts critical policies and procedures entrenched in a firm to prevent it from falling into crisis because of poor or weak management (Bouziane \& Belhadef, 2017). There is therefore an urgent need to build stakeholders' confidence in the company through reliable control that will permit stakeholders' engagement in developing IC.

Corporate Governance (CG) is defined as a control mechanisms implemented in a firm for the creation of profit sharing system and to create a balance between wealth for shareholders and efficiencies in company management (Arifin \& Arifin, 2014). It also means governance laws and regulations for acceptable business practices (Yosuff \& Alhaji, 2012). In a simpler term, it means the procedural control and directive in management of a business entity. Basically, corporate governance is of two dimensions. It is a structure of accountability for firm management and on the other hand it describes relationship and division of roles between various existing management teams. In literature, corporate governance variables have been linked to corporate performance, but the role of corporate governance variables in improving firms' IC has received a little attention.

\section{Intellectual Capital, Corporate Governance and Firm Performance}

The major initiative for developing IC has to come from management if the initiative is to prove successful. Building a company capability to develop knowledge is highly depending on the board of directors. This is because how they perceive and interprets IC determines the motivation they will give to employees, the role they will play to ensure the investment in IC yields positively. It is the role of management is to bring together expertise and experienced employees that will bring improvements and innovations that the customers are willing to pay for. According to Bukowitz et al. (2014), bringing together expertise and experienced employees' depicts eliminating barriers that has to do with 
functional domains and organization structures.

It is imperative to constantly increase corporate knowledge and capabilities in order to create value efficiently. In lieu of this, managers have to improve their capability and adopt the classic way of doing business which transcend professional competence rather inclusiveness of social competence and team work. The level of a firm performance is dependent on the way managers of the organization carried out the tasks assigned to them. Considering stewardship theory in relation to corporate governance and IC, the theory focuses on behavior of executives. Management (board of directors) are seen as stewards whose behavior will not deviate or conflict the interest of the organization as the firm seeks to attain the objectives of the organization and satisfies the requirements of all interested stakeholder which will result in dynamic performance and balanced governance (Yosuff \& Alhaji, 2012).

\section{Empirical Review}

Aftab et al. (2019) investigated connection between IC and market value of 79 quoted non-financial companies spanning from 2010 to 2015 using regression analysis techniques. Value Added Intellectual Coefficient (VAIC) model was used for the computation of IC. Tobin's Q was employed as a proxy for firm value. Managerial ownership was tested as a moderator. Findings revealed positive significant relationship between IC and firm value while managerial ownership moderates the relationship between IC and firm value negatively.

Olayiwola (2018) studied the influence of corporate governance on the performance of 10 Nigerian quoted companies from year 2010 to 2016 using regression analysis techniques. The CG was proxied with board size, audit committee size and board composition while performance was proxied with net profit margin. The study revealed that board size had a strong negative relationship with net profit margin (NPM), board composition had a significant positive correlation with NPM, audit committee size had an insignificant correlation with NPM and board size, audit group size and composition of board significantly influence NPM. Study concluded that smaller board size increase performance and the board composition ought to consist more of the non- executive directors and constant review of audit committee.

Aslam et al. (2018) assessed effect of CG and IC on firm's performance and CSR disclosures of Australian Stock Exchange (ASX) listed companies. Their study employed PLS-SEM method for 10 different sectors with 26 industry group in year 2014 . Findings showed Australian companies are more environmental-friendly because of sound CG practiced. Also, results revealed that both CG and IC are related with improved firms' financial performance of companies.

Shahveisi and Khairollahi (2017) undertook an empirical research on the connection among different ownership types on IC of 100 quoted companies in Iran from year 2005 to 2009 using both correlation and multiple regression analysis techniques. Their results showed strong connection among institutional, concentration ownership and IC performance.

Obigbemi, Mukoro, Adetula and Owolabi (2016) looked at the role of CG mechanisms on the performance of listed 137 firms in Nigeria from year 2003 to 2010 using regression analysis techniques. Their study used ROA, board characteristics, management ownership, block ownership, duality of Chairman and CEO post were used as proxy for CG mechanisms. Findings revealed strong connection among board characteristics and management ownership with performance of companies in Nigeria with negative relationship among block ownership, CEO post and performance of companies in Nigeria.

Sakariyahu and Jimoh (2016) studied the influence of $C G$ practices on the performance of 12 quoted firms on the ASeM in Nigeria for the period of 2009 to 2015 using regression analysis techniques. The findings revealed strong effect of $\mathrm{CG}$ on performance of companies listed on the ASEM at 5\% level of significance. This study concluded that CG practices are an essential factor that determines firms' performance. Their study recommended that organizations must strictly comply with CG principles, maintain 
moderate board size and ensure independence of audit committee as prescribed by international standards. Strict adherence to Securities and Exchange Commission code of governance is also vital as this would help instil boost performance of the firms listed on ASeM and generally improve the image of the Nigerian business environment.

Basyith (2016) investigated the influence of CG and IC on firm performance of 120 firms on Indonesian listed companies from 2009 to 2013. His study adopted non-linear Generalized Method of Moments (GMM) and Standard Least Square method. Findings revealed strong influence of $\mathrm{CG}$ on firm performance. Pongpearchan (2016) investigated influence of IC on company performance of 925 businesses in Thailand during the year 2015. The study employed a structured questionnaire with stratifies random sampling method using five-point Likert's scale. Regression analysis technique was employed and findings showed significant influence of organisation capital on value creation.

\section{Underpinning Theory}

The main theory underlying the study is Resource-Based View (RBV) theory. RBV was initiated in the mid-1980s by Wernerfelt (1984), Rumelt (1984) and Barney (1986) and it has since become one of the dominant contemporary approaches to the analysis of sustained competitive advantage. The theory assumes that the performance of a firms and the competitive advantage it enjoys is highly depending on the resources available and at the company's disposal. Ardi and Etty (2018) in their study align with the assumption of RBV theory as they submit that a company's competitive advantage is derived from its ability to pull together and utilize appropriately the right combination of resources. The resources of a company is not limited to its physical assets, as the knowledge inputs in the company's production process; expertise and professionalism of employees, patents, financing and talented managers are all part of resources of the firm.

$\mathrm{RBV}$ recognizes the strategic importance of social and behavioral interactions (relational capital) as one of the choices way in achieving organization objective (performance). In 1997, Edvinsson and Malone carried out a study on the relationship between intangible asset and firm performance, and it was discovered that the gap between the book value and market value of the firms is the contribution of intangible assets and intellectual property. This means that, IC has an influence on firm value because it's a resource that boosts performance beyond returns on sales. In relating CG with IC, resource dependence theory offers an explanation of the role of the board of directors as a resource to the firm. According to Pfeffer and Salancik (1978), organizations attempt to exert control over their environment by bringing into the firm resources (which can be human; structural; relational) necessary to survive on which the onus is on the board of directors to attract indispensable resources which the organization needs to survive and flourish.

According to Marr and Schiuma (2004), organizational capabilities are based on knowledge and since knowledge is a resource that forms the foundation of company capabilities, the ownership of specific knowledge provides organization with specific capabilities. They noted that the possession of knowledge enables specific capabilities and hence, only the management of the knowledge will help an organization identify, maintain and refresh its competencies in the short and long run (Surdarsanam et. al., 2013). This study can therefore be related to this theory as the knowledge acquired by firms are the IC and the firms can enhance their performance based on the knowledge by harnessing its Human Capital Efficiency (HCE), Structural Capital Efficiency (SCE) and Capital Employed Efficiency (CCE).

\section{Method}

The study adopted ex-post facto research design. Financial Performance was measured using return on asset (ROA) and return on equity (ROE) while IC was proxy by human capital (HC), structural capital (SC) and customer capital (CC). Also, corporate governances were proxies by audit committee size, board size, proportion of attendance in meeting, audit committee meeting, proportion of independent directors in the audit and risk 
committee and log of managerial ownership structure. The study population comprised 80 listed non-financial companies on Nigerian Stock Exchange (NSE). Using purposive sampling, the sample size of 50 listed nonfinancial firms was selected and data were extracted from their annual audited accounts and reported between 2007 and 2017. The study employed multiple regression analysis.

This study employed baseline model adapted from Ahangar (2011) and Kurfi et al. (2017) which was in line with the Knowledgebased Theory. The baseline model functional relationship among performance, IC and corporate governance was given in the model below:

$R O A=f(I C, C G)$

The performance indicator of ROA resulted into equation 2

$$
R O A_{i t}=\overrightarrow{\mathrm{f}\left(V A I C^{T M}\right)}
$$

The vector is decomposed into HCE, SCE and CEE. This result into the equation below:

$$
\begin{aligned}
& R O A_{i t}=\beta_{0}+\beta_{1} H C E_{i t}+\beta_{2} S C E_{i t}+ \\
& \beta_{3} C E E_{i t}+e_{i t}
\end{aligned}
$$

This model is further expanded with the inclusion of Corporate Governance variables and the control variables in line with the study of Kurfi et al., 2017 and Nwaiwu \& Nwaekpe (2018). This result into the equation below:

$R O A_{i t}=\beta_{0}+\beta_{1} A S_{i t}+\beta_{2} B S_{i t}+$ $\beta_{3} A C M_{i t}+\beta_{4} B M T_{i t}+$

$$
\begin{aligned}
& \beta_{5} B I N D_{A R_{i t}}+\beta_{6} L M O_{i t}+\beta_{7} A G E_{i t}+ \\
& \beta_{8} L E V_{i t}+\beta_{9} H C E_{i t}+\beta_{10} S C E_{i t}+ \\
& \beta_{11} C E E_{i t}+ \\
& e_{i t}
\end{aligned}
$$

With the inclusion of corporate governance index as one variable and this result into the equation below:

$$
\begin{aligned}
& R O A_{i t}=\beta_{0}+\beta_{1} H C E_{i t}+\beta_{2} S C E_{i t}+ \\
\beta_{3} C E E_{i t}+\beta_{4} A G E_{i t}+\beta_{5} L E V_{i t}+\beta_{6} G_{i t} & +{ }_{7} H C E * C G_{i t}+\beta_{8} S C E * C G_{i t} \\
& +\beta_{10} C E E * C G_{i t} \\
& +e_{i t}
\end{aligned}
$$

Where: ROA $=$ Return on Asset; HCE $=$ Human Capital Efficiency; SCE = Structural Capital Efficiency; CEE = Capital Employed Efficiency; AS = Audit Committee Size; BS =Board Size; $\mathrm{BMT}=$ Proportion of Attendance in meeting; $\mathrm{ACM}=$ Audit Committee Meeting; BIND_AR = Proportion of Independent Directors in Audit and Risk Committee; $\mathrm{LMO}=\log$ of Managerial Ownership Structure; AGE $=$ the numbers of years the companies are in operation; LEV = Leverage is the total debt to equity ratio

\section{Results and Discussion}

This section reveals the analysis of the moderating role of corporate governance on the relationship between IC and financial performance of quoted non-financial companies in Nigeria. Table 1 presents the descriptive analysis of the data. The industry had an average audit committee size (AS) of 5.444 , a median of 6.00 coupled with

Table 1. Descriptive Statistics of the variables

\begin{tabular}{ccccccccc}
\hline & Mean & Median & Maximum & Minimum & $\begin{array}{c}\text { Std. } \\
\text { Dev. }\end{array}$ & Skewness & Kurtosis & Observations \\
\hline ROA & 0.077 & 0.046 & 7.856 & -3.505 & 0.454 & 7.867 & 165.994 & 550 \\
ACM & 3.459 & 4.000 & 8.000 & 0.000 & 0.944 & 0.122 & 5.568 & 550 \\
AGE & 47.146 & 48.000 & 94.000 & 2.000 & 20.316 & 0.100 & 2.703 & 550 \\
AS & 5.444 & 6.000 & 8.000 & 0.000 & 1.004 & -1.574 & 6.340 & 550 \\
BIND_AR & 5.595 & 5.000 & 15.000 & 0.000 & 2.135 & 0.381 & 3.915 & 550 \\
BMT & 3.627 & 4.000 & 9.000 & 0.000 & 2.064 & -0.564 & 2.605 & 550 \\
BS & 8.924 & 9.000 & 18.000 & 0.000 & 2.482 & 0.465 & 3.742 & 550 \\
CEE & -0.021 & 0.000 & 10.639 & -11.858 & 1.137 & -0.320 & 43.405 & 550 \\
HCE & 0.686 & 0.193 & 40.408 & -45.136 & 5.601 & -0.622 & 32.061 & 550 \\
LEV & 2.203 & 1.305 & 71.572 & -34.299 & 6.146 & 5.472 & 61.107 & 550 \\
LMO & 15.433 & 15.662 & 20.999 & 8.619 & 2.949 & -0.007 & 2.101 & 550 \\
SCE & 0.567 & 0.921 & 15.713 & -13.352 & 1.743 & 0.061 & 24.550 & 550 \\
\hline
\end{tabular}

Source: Author's Computation (2020) 
Table 2. Correlation

\begin{tabular}{|c|c|c|c|c|c|c|c|c|c|c|c|c|}
\hline \multicolumn{13}{|c|}{ Correlation } \\
\hline Probability & ROA & ACM & AGE & AS & BIND_AR & BMT & BS & CEE & $\begin{array}{c}\text { FIRM_ } \\
\text { SIZE }\end{array}$ & $\mathrm{HCE}$ & LEV & $\begin{array}{ll}\text { LMO } & \text { SCE }\end{array}$ \\
\hline \multirow[t]{2}{*}{$\overline{\mathrm{ROA}}$} & 1.0000 & & & & & & & & & & & \\
\hline & ----- & & & & & & & & & & & \\
\hline \multirow[t]{2}{*}{$\mathrm{ACM}$} & 0.0114 & 1.0000 & & & & & & & & & & \\
\hline & $(0.8532)$ & ----- & & & & & & & & & & \\
\hline \multirow[t]{2}{*}{ AGE } & 0.0159 & 0.2787 & 1.0000 & & & & & & & & & \\
\hline & $(0.7970)$ & $(0.0000)^{*}$ & ----- & & & & & & & & & \\
\hline \multirow[t]{2}{*}{ AS } & 0.0786 & 0.4372 & 0.2498 & 1.0000 & & & & & & & & \\
\hline & $(0.2029$ & $(0.0000)^{*}$ & $(0.0000)^{*}$ & ----- & & & & & & & & \\
\hline \multirow[t]{2}{*}{ BIND_AR } & 0.0698 & 0.1773 & 0.0200 & 0.2244 & 1.0000 & & & & & & & \\
\hline & $(0.2580)$ & $(0.0038)^{*}$ & $(0.7458)$ & $(0.0002)^{*}$ & ---- & & & & & & & \\
\hline \multirow[t]{2}{*}{ BMT } & 0.0937 & 0.2728 & 0.2938 & 0.5378 & 0.1254 & 1.0000 & & & & & & \\
\hline & $(0.1286)$ & $(0.0000)^{*}$ & $(0.0000)^{*}$ & $(0.0000)^{*}$ & $(0.0416)^{*}$ & ---- & & & & & & \\
\hline \multirow[t]{2}{*}{ BS } & -0.0057 & 0.2494 & 0.1578 & 0.4637 & 0.6166 & 0.2398 & 1.0000 & & & & & \\
\hline & $(0.9262)$ & $(0.0000)^{*}$ & $(0.0102)^{*}$ & $(0.0000)^{*}$ & $(0.0000)^{*}$ & $(0.0001)^{*}$ & ---- & & & & & \\
\hline \multirow[t]{2}{*}{ CEE } & 0.1368 & 0.0011 & 0.0192 & 0.0585 & 0.0245 & 0.1035 & -0.0044 & 1.0000 & & & & \\
\hline & $\begin{array}{r}(0.0262) \\
*\end{array}$ & $(0.9845)$ & $(0.7550)$ & (0.3436) & $(0.6918)$ & $(0.0932)$ & $(0.9428)$ & ----- & & & & \\
\hline \multirow{2}{*}{$\begin{array}{l}\text { FIRM_SIZ } \\
\text { E }\end{array}$} & -0.0354 & 0.2866 & 0.1555 & 0.4240 & 0.1249 & 0.2188 & 0.3462 & 0.0297 & 1.0000 & & & \\
\hline & $(0.5665)$ & $(0.0000)^{*}$ & $(0.0114)^{*}$ & $(0.0000)$ & $(0.0425)^{*}$ & $(0.0003)^{*}$ & $(0.0000)^{*}$ & $(0.6301)$ & ----- & & & \\
\hline \multirow[t]{2}{*}{ HCE } & -0.0713 & 0.0963 & 0.0186 & 0.0490 & 0.0473 & 0.0162 & -0.0046 & -0.0577 & 0.0638 & 1.0000 & & \\
\hline & $(0.2483)$ & $(0.1182)$ & $(0.7635)$ & (0.4273) & $(0.4436)$ & (0.7929) & (0.9398) & $(0.3502)($ & $(0.3010)$ & ----- & & \\
\hline \multirow[t]{2}{*}{ LEV } & 0.0025 & 0.0233 & 0.1043 & -0.0791 & -0.0384 & 0.0409 & -0.0680 & -0.4873 & 0.1070 & 0.0271 & 1.0000 & \\
\hline & $(0.9676)$ & $(0.7062)$ & $(0.0908)$ & (0.1997) & $(0.5345)$ & (0.5077) & $(0.2707)$ & $(0.0000) *$ & $(0.0824)($ & $0.6604)$ & ---- & \\
\hline \multirow[t]{2}{*}{ LMO } & -0.1352 & -0.1121 & -0.3491 & -0.0361 & 0.0665 & -0.1289 & 0.1064 & -0.0855 & -0.1077 & 0.0019 & -0.1316 & 1.0000 \\
\hline & $(0.0280)$ & (0.0689) & $(0.0000)^{*}$ & $(0.5585)$ & $(0.2810)$ & $(0.0362)^{*}$ & $(0.0843)$ & $(0.1656)($ & $(0.0805)$ & $0.9754)$ & $(0.0325)^{*}$ & ---- \\
\hline \multirow[t]{2}{*}{ SCE } & -0.0148 & -0.0537 & -0.0423 & -0.016 & -0.0092 & -0.0371 & -0.0502 & 0.0749 & 0.0672 & -0.0138 & -0.0495 & 0.06621 .0000 \\
\hline & $(0.8106)$ & $(0.3848)$ & $(0.4929)$ & $(0.7914)$ & $(0.8817)$ & $(0.5478)$ & $(0.4163)$ & $(0.2247)($ & $(0.2763)$ & $0.8225)$ & $(0.4223)($ & (0.2807) --- \\
\hline
\end{tabular}

Source: Author's Computation (2020)

maximum and minimum value of 8.00 and 0.000 respectively. It implies the fact that most of the firms had almost similar number of audit committee size. The value of industry average and median of audit committee size too closely netted owing to the fact the corporate governance code stipulate that audit committee size should not be more than 8 . In the same vein, the mean and median of Audit committee meetings (ACM) is 3.45 and 4.00 respectively with a maximum and minimum value of 8.00 and 0.000 . Also, its standard deviation is 0.944 and skewness is 0.122 while the Kurtosis is 5.56. This is another pointer to the strict compliance with corporate governance code of the listed firms in Nigeria. The law made it clear that not less than three audit committee meetings must be held per financial year. The low degree of dispersion is a reflection of the fact that firms in the samples held almost the same number of audit committee meetings. The board meeting (BMT) mean value is 3.62 while the median is 4.00. The standard deviation BMT indicates low level of dispersion among the firms. The board meetings distribution of the firms is evenly distributed with low degree of dispersion. It is expected that the firms will report almost similar number of board meetings, owing to the fact that adherence to corporate governance is expected. It is not a surprise for LEV of the pooled firms to exhibit high degree of dispersion, because firms leverage is a function of management quality and structural framework. The leverage of big firms will be much difference from leverage of small firms. The mean of 2.20 and a median of 1.305 report that the sampled firms leverage is not highly skewed. Age of the firm was expected to be dispersed. Age (AGE) report mean of 47 years and median of 48 years over the sampled period. The board size (BS) also report low level of dispersion owing to the strict regulation prevailing the corporate governance structures of most companies in Nigeria. 
The correlation matrix shows the relationship between the dependent and the independent variables. The result also shows the relationship that exists between the independent variables and further shows symptoms of multi-collinearity if any. The result obtained shows that there exists a relationship between the dependent variable and the independent variables. This is an indication that the independent variables of the research can affect the dependent variable. Also, the result indicated that the explanatory variables were not exhibiting serious correlation with one another. This informed the inclusion of all the explanatory variables in the model. Table 2 demonstrates that the regressors are not multi-collinear.

Table 3 presents the results of regression of the moderating role of corporate governance on the relationship between IC and financial performance of quoted nonfinancial companies in Nigeria. The model was estimated using Fixed Effect and Random Effects assumption. The study sampled 50 quoted non-financial companies from 2007 to 2017. ROA was used as a measure of performance. CG Variables were Audit Committee Size (AS), Board Size (BS), Audit Committee Meeting (ACM), Proportion of Independent Directors in Audit and Risk Committee (BIND_AR) and Managerial Ownership Structure (LMO). However, in order to reduce the tendency of weak parameters, Hausman test for correlated random effects was conducted to provide the best model estimates for the data (see Table 3 for result) and consider if the variance in the estimates of the random and fixed effect models are significant to cause biasness of the model parameters. The Hausman test (Chi-Sq. statistics) rejects random effect assumption

Table 3. Moderating Role of Corporate Governance on the Relationship between IC and Performance of Quoted Non-Financial Companies in Nigeria

\begin{tabular}{|c|c|c|}
\hline $\begin{array}{l}\text { Method: } \\
\text { Dep. Var: }\end{array}$ & $\begin{array}{c}\text { FIXED EFFECT } \\
\text { ROA }\end{array}$ & $\begin{array}{c}\text { RANDOM EFFECT } \\
\text { ROA }\end{array}$ \\
\hline \multirow[t]{2}{*}{ CG } & 0.3674 & 0.2289 \\
\hline & {$[0.2160]$} & {$[0.1551]$} \\
\hline \multirow[t]{2}{*}{$\mathrm{CEE}^{*} \mathrm{CG}$} & 1.2436 & 1.1837 \\
\hline & {$[2.7389]^{* *}$} & {$[1.9400]^{*}$} \\
\hline \multirow[t]{2}{*}{$\mathrm{HCE}^{*} \mathrm{CG}$} & 0.0414 & -0.0517 \\
\hline & {$[2.2293]^{* *}$} & {$[-2.2446] * *$} \\
\hline \multirow[t]{2}{*}{$\mathrm{SCE}^{*} \mathrm{CG}$} & 0.5842 & 0.3159 \\
\hline & {$[2.1051]^{* *}$} & {$[0.4141]$} \\
\hline \multirow[t]{2}{*}{ AGE } & -1.5307 & 0.0844 \\
\hline & {$[-2.7755]^{* *}$} & {$[0.8061]$} \\
\hline \multirow[t]{2}{*}{ CEE } & 14.5293 & 14.7616 \\
\hline & {$[12.9183]^{* *}$} & [1.6297] \\
\hline \multirow[t]{2}{*}{$\mathrm{HCE}$} & 0.2231 & 0.3366 \\
\hline & {$[2.1617]^{* *}$} & {$[0.2122]$} \\
\hline \multirow[t]{2}{*}{ SCE } & 4.2874 & -2.0796 \\
\hline & {$[2.3288]^{* *}$} & {$[-2.3558] * *$} \\
\hline \multirow[t]{2}{*}{ LEV } & 1.4015 & 1.2411 \\
\hline & {$[2.5309]^{* *}$} & {$[4.3664]^{* *}$} \\
\hline \multirow[t]{2}{*}{$\mathrm{C}$} & 74.9782 & -0.0556 \\
\hline & {$[2.6949] * *$} & {$[-0.0048]$} \\
\hline Observations: & 550 & 550 \\
\hline$R$-squared: & 0.4217 & 0.3127 \\
\hline -F-statistic: & 16.0914 & 28.8689 \\
\hline $\operatorname{Prob}(F-$-stat $):$ & 0.0000 & 0.0000 \\
\hline Hausman Test & $33.167563(\mathrm{p}<0.05)$ & \\
\hline
\end{tabular}

Note: $* * *, * *$ and $*$ reveals that variable is significant at $1 \%, 5 \%$ and $10 \%$ respectively.

Source: Author's Computation (2020) 
that unobserved firm specific heterogeneity are uncorrelated with explanatory variables and so, the study employed the Fixed Effect Method (FEM) which is the most appropriate model to interpret the result of the analysis.

HCE showed a value of 0.22 which implied a positive relationship with ROA $(\mathrm{t}=2.1617, \mathrm{p}<0.05)$. This showed that the nonfinancial firms listed at the NSE between 2007 and 2017 on average of 0.22 funds for the labours that can create value added. The positive relationship between ROA and HCE indicated that $\mathrm{HC}$ can aid the profitability and create value in the company. Also, optimal utilization of human resources leads to competitive advantages that may ultimately improve the financial performance and corporate value.

SCE showed an average coefficient of 0.28 . The variable had positive relationship with ROA ( $\mathrm{t}=2.3288, \mathrm{p}<0.05)$. This showed that SCE contributed 0.280 in the firm value creation. CEE had positive significant effect on ROA $(t=12.9183, p<0.05)$. This indicated that rise in CEE can enhance the profitability of non-financial firms of Nigeria. HCE had positive relationship with ROA $(\mathrm{t}=2.1617$, $\mathrm{p}<0.05)$. Leverage ratio had positive relationship with ROA $(\mathrm{t}=2.5309, \mathrm{p}<0.05)$. Corporate Governance (CG) had moderating effect on the relationships between IC and the firm performance through the CEE $(t=2.7389$, $\mathrm{p}<0.05)$, HCE $(\mathrm{t}=2.2293, \mathrm{p}<0.05)$ and also SCE $(t=2.1051, p<0.05)$. Strong corporate governance system serves as a good platform to induce efficiency in the firm. The Fstatistics test of the significance of the model indicates that the model was statistically significant at 5\% level of significance. The $\mathrm{R}^{2}$ coefficient was used in determining the coefficient of determination of the model, the $\mathrm{R}^{2}$ value of 0.42 , implied that about 43 percent of variation in ROA was explained by changes in selected firm-specific variables.

Findings of this study agree with the findings of Hamadan et. al., (2017) which asserted that corporate governance significantly influenced IC and firms' financial performance. Also, the findings of this study are supported by the findings of Aslam et. al., (2018) which concluded that both corporate governance and IC are related with improved firms' financial performance and Afab et. al., (2019) which concluded that there is a positive and significant relationship between IC and firm value while moderating variable of ownership structure as a corporate governance mechanism has a negative impact on firm value.

\section{Conclusion and Recommendations}

The study investigates the moderating role of corporate governance on the relationship between IC and performance of quoted non-financial companies in Nigeria during an eleven years period. Thus, the results from the study indicate that that corporate governance had moderating effect on the relationships between IC and the firm performance through the capital employed efficiency, human capital efficiency and structural capital efficiency. This study has its own limitation because it is only carried out on quoted non-financial companies and the result cannot be used to generalize what happened in other sectors like financial institutions and service oriented firms. Also it only makes use of financial performance measures while non-financial performance measures that may explain the situations also were not included. The study recommends that Board of directors should adopt measurable corporate governance mechanism which strengthens and helps in investment strategy that increases and improves performance. Also, there is need to entrench corporate governance as a control strategy and impetus towards attaining organization's goals.

\section{References}

Adegbite, E. (2012). Corporate governance and responsibility in Nigeria. International Journal of Disclosure and Governance, 21(2), 93-104

Adesanmi, A. D., Sanyaolu, O. A., Ogunleye, O. O. \& Ngene, T. W. (2018). Corporate governance and firm's financial performance. A comparative study of manufacturing companies and banks in Nigeria. International Journal of Contemporary Research and Review. 9(7), 209-219 
Adetunji, M. B., \& Olawoye, O. (2009). The effects of internal and external mechanism on governance and performance of corporate firms in Nigeria. Journal of Corporate Ownership \& Control, 2(3), 1-7.

Arifin, S., \& Arifin Z. (2014). The influence of corporate governance, intellectual capital on financial performance and firm value of bank sub-sector companies listed at Indonesia stock exchange in Period 2008-2012. European Journal of Business and Management, 6(26), 159-167.

Aftab A., Khurshid, M. K., \& Yousaf, M. U. (2019). Impact of intellectual capital on firm value: The moderating role of managerial ownership. Preprints 2019, 2019010318 (doi:10.20944/preprints201901.0318. v1).

Ahangar, R. G. (2011). The relationship between intellectual capital and financial performance: An empirical investigation in an Iranian company. African Journal of Business Management, 5(1), 88-95.

Ahmad, M., (2011). The impact of corporate governance and intellectual capital on firm's performance and corporate social responsibility disclosure. Journal of Commerce and Social Science, 12(1), 283-308.

Ahmad, S. \& Mushraf, A. M. (2011). The relationship between intellectual capital and business performance: An empirical study in Iraqi industry. International Proceedings of Economics Development and Research, 6, 104-109.

Aiwanehi, B. O., Abdul-Hameed. A. Sulaimon, S., Abayomi, A. (2018). Corporate governance practices: A comparative study of selected public corporations in Nigeria. Academic Journal of Economic Study, Faculty of Finance, Banking and Accountancy Bucharest, "Dimitrie Cantemir", Christian University Bucharest, 4(1), 192-202.
Akinkoye, E. Y. and Olasanmi, O. O. (2014). Corporate governance practice and level of compliance among firms in Nigeria: Industry analysis. Journal of Business and Retail Management Research (JBRMR), 9(1), 3-11.

Alipour, M. (2012). The effect of intellectual capital on firm performance: An investigation of Iran insurance companies. Measuring Business Excellence, 16 (1), 53-66.

Anuonye, N. B. (2015). Intellectual capital measurement: Using the earnings per share model of quoted insurance companies in Nigeria. International Business and Management, 10(1), 88-98.

Araniyar, I. C., \& Chizea, J. J. (2017). Corporate governance disclosure in developing countries: A comparative analysis in Nigerian and South African banks. SAGE Open, https://doi.org/10.1177/2158244017 719112

Aslam, S., Ahmad, M., Amin, S., Usman, M., \& Arif, S. (2018). The impact of corporate governance and intellectual capital on firm's performance and corporate social responsibility disclosure. Journal of Commerce and Social Science, 12(1), 283-308.

Basyith, A. (2016). Corporate governance, intellectual capital and firm performance. Research in Applied Economics, 8(1), 17. ISBN 19485433.

Bezawada, B. (2020). Corporate governance and bank performance: Evidence from Indian banks. Indian Journal of Finance and Banking, 4(1), 33-41. Doi:10.46281/ijfb.v4i1.502.

Brannstrom, D., \& Giuliani, M. (2009). Accounting for intellectual capital: A comparative analysis. VINE, 39(1), 68-79.

Bouziane, A., \& Belhadef, S. (2017). The importance of human resources in corporate governance. Mediterranean Journal of Social Sciences, 8(4), 161 $-164$. 
Bukowitz, W.R., Cristina, C., Henrik, J., Hanno, R., Willam, R. (2014). How to develop and monitor your company's intellectual capital: Tools and actions for the competency-based organization. Publication of Nordic Industrial Fund and the Employers' Confederations in the Nordic countries. Retrieved from www.icframe.net

Chen, M. C., Chen, S. J., \& Hwang, Y. (2005). An empirical investigation of the relationship between intellectual capital and firm's market value and financial performance. Journal of Intellectual Capital, 6(2), 159-176.

Chizari, M. H., Mehrjardi, R. Z., Sadrabadi, M. M., \& Mehrjardi F. K. (2016). The impact of intellectual capital of pharmaceutical company's listed in Tehran stock Exchange on their market performance. The Learning Organisation, 14(3), 241-262.

Clarke, T., Tan, H. P., Plowman, D. \& Hancock, P. (2007). Intellectual capital and financial returns of companies, Journal of Intellectual Capital, 10(4), 588-599.

Clarke, M., Seng, D., \& Whiting, R.H. (2011). Intellectual capital and firm performance in Australia. Journal of Intellectual Capital, 12(4), 505-530.

Firer, S., \& Williams, M. (2003). Intellectual capital and traditional measures of corporate performance. Journal of Intellectual Capital, 4(3), 348-360.

Gyamerah, S. \& Agyei, A. (2016). OECD principles of corporate governance: Compliance among Ghanaian listed companies. International Journal of Advanced Multidisciplinary Research. 3(11), 82-92.

İlhan, Ç. (2019). The moderating effect of human capital on innovation capital and firm market value. International Journal of Accounting and Financial Reporting, 5(5), 23-28.

Irawanto, D. W., Gondomono H. \& Hussein S. A. (2017). The effect of intellectual capital on a company's performance moderated by its governance and it strategy integration employed by banks listed in Indonesian Stock Exchange. The South East Asian Journal of Management, 11(2), 86102.

Kurfi, S. A., Udin, N. M., \& Bahamman, S. M. (2017). The impact of intellectual capital on the financial performance of listed Nigerian food products companies. Journal of Accounting and Taxation, 9(11), 147-160.

Marr, B., Schiuma, G., \& Neely, A. (2004). The dynamics of value CreationMapping Your Intellectual Performance Drivers. Journal of Intellectual Capital, 5, 312-325.

Nasar, S. (2018). Impact of intellectual capital on firm performance of the Turkish real estate companies before and after the crisis. European Scientific Journal, 14(1), 45-60

Nwaiwu, J. N., \& Nwaekpe, U. C. (2018). Webometric analysis of intellectual capital reporting and corporate financial performance in Nigeria. International Journal of Innovative Finance and Economics Research, 6(1), 75-98.

Obigbemi, I. F., Mukoro, D. O., Adetula, D. T. \& Owolabi, F. A. (2016). Corporate governance mechanism and financial performance of companies. Journal of South African Business Research. Available at http://www.ibimapublishing.com/jou rnals/JSABR/jsab.

Olayiwola, K. T. (2018). The effect of corporate governance on financial performance of listed companies in Nigeria. European Journal of Accounting, Auditing and Finance Research. 6(9) 85-98.

Onyekwelu, U. L., Okoh, J. I., \& Iyidiobi, F. C. (2017). Effect of intellectual capital on financial performance of banks in Nigeria. European Journal of Accounting, Auditing and Finance Research, 5(2), 28-57. 
Payam, M., \& Mohammad, A. (2013). The effects of intellectual capital on economic value added in Malaysians companies. Current Research Journal of Economic Theory, 5(2), 20-24.

Pongpearchan, P. (2016). The influence of intellectual capital on firm performance of computer businesses in Thailand. International Business Management, 10, 438-445.

Pulic, A. (2000). An accounting tool for intellectual capital management. International Journal of Technology Management, 20, 702-714. 